DIRECTOR

Judith C. Russell

EDITOR IN CHIEF

Laurie N. Taylor

MANAGING EDITOR \& DESIGNER

Tracy E. MacKay-Ratliff

\section{COMMUNICATIONS DIRECTOR}

Barbara Hood

\section{ASSOCIATE EDITOR}

Chelsea Johnston

SOURCE COMMITTEE

All members listed above and

Lauren Adkins

April Hines

Ellen Knudson

Suzanne C. Stapleton

\section{CONTRIBUTORS}

Listed in Table of Contents

FIND US ONLINE

ufdc.ufl.edu/source

MORE INFO \& SUBMISSIONS

journals.fivc.org/source

\section{CONTACT US}

Have a story you'd like to see featured in SOURCE? Send us your ideas!

SOURCE@UFLIB.UFL.EDU

SUBSCRIBE TO SOURCE

SOURCE@UFLIB.UFL.EDU

SUPPORTING THE LIBRARIES

Smathers Libraries thanks you! Support from private donors like you is essential to continue to build the collections-both print and electronicand provide outstanding services to students and faculty.

DEVELOPMENT OFFICE UFLIB.UFL.EDU/GIVING (352)273-2505

\section{LP国UF}

LIBRARYPRESS@UF

AN IMPRINT OF UF PRESS AND GEORGE A. SMATHERS LIBRARIES UNIVERSITY of FLORIDA

PO Box 117000, Gainesville, FL 32611 $352 / 273.2635$

http://librarypress.domains.uflib.ufl.edu

\section{FALL 2021 VOL. 4 , ISSUE 1}
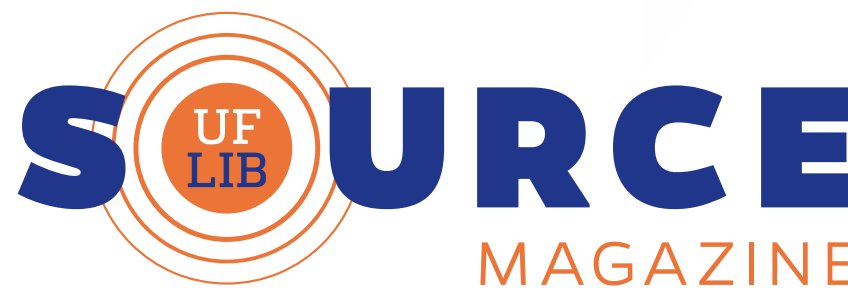

MAGAZINE

\section{Highlights \& Spotlights}
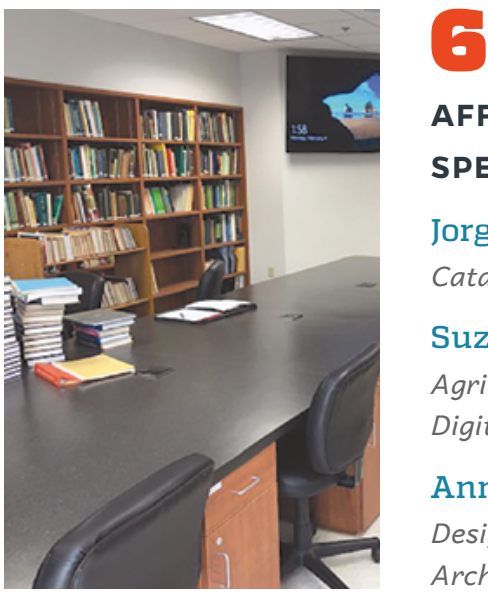

\author{
AFFILIATED LIBRARIES FEATURE \\ SPECIALIZED COLLECTIONS \\ Jorge Gonzalez \\ Cataloging Liaison \\ Suzanne Stapleton \\ Agricultural Sciences \& \\ Digital Scholarship Librarian \\ Ann Baird \\ Design Librarian, \\ Architecture \& Fine Arts Library
}

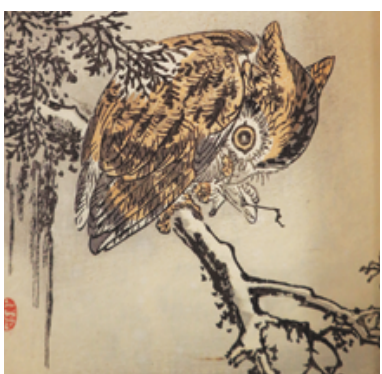

\section{0}

\section{UNDERGRADUATE \\ DISCOVERY FELLOWSHIPS IN SPECIAL COLLECTIONS}

Neil Weijer

Curator of the Rare Book Collection
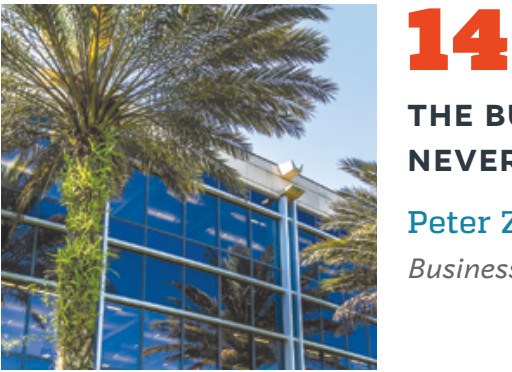

THE BUSINESS LIBRARY NEVER SLEEPS

Peter Z. McKay

Business Librarian

*NOTE: Some images in this issue of SOURCE were taken prior to national guidelines of face coverings and physical distancing. 
- THE FINE ARTS COMPLEX, FEATURING

ARCHITECTURE AND FINE ARTS LIBRARY

$a_{3} x^{2}+2$.

LIBRARY SPACES ON THE COVER

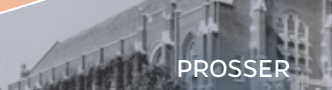

GARDEN

LOCATION

NEAR

SMATHERS
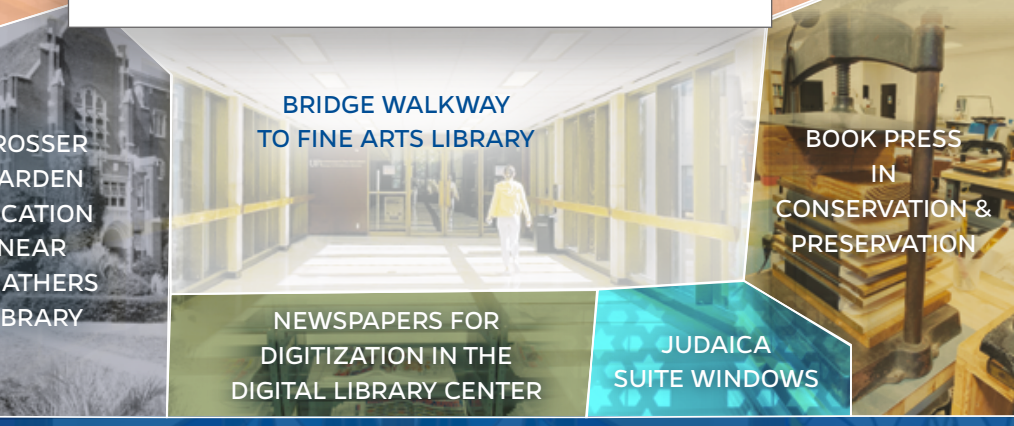

More Reflections, Stories, \& Aspirations of the UF Smathers Libraries

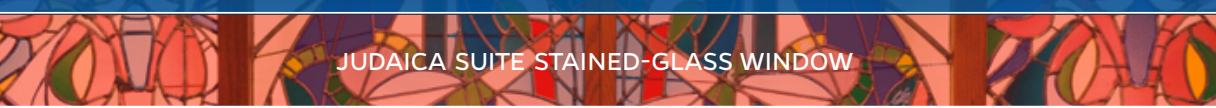

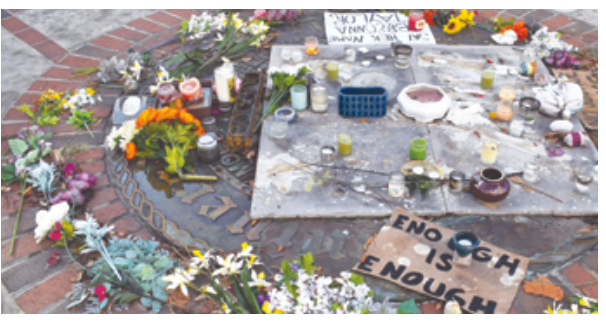

2

REFLECTIONS ON COMMUNITY ARCHIVING FOR SOCIAL JUSTICE

Tiffany Pennamon

English Doctoral Student \& 2020-21

University \& Community Life Intern

Sarah Coates, CA

Interim University Archivist \&

Intership Project Supervisor

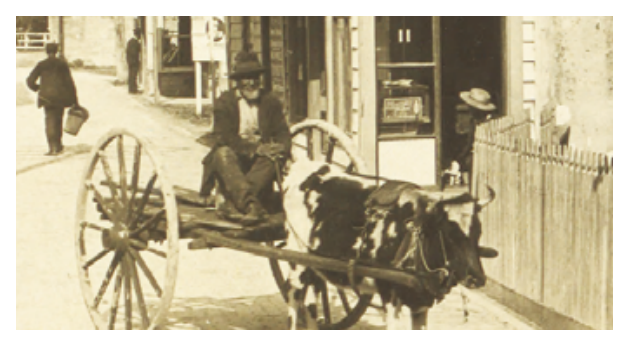

19

RESILIENCE: CENTERING BLACK HERITAGE IN ST. AUGUSTINE

Laura Marion

Collections Coordinator

Casey Wooster

Collections Assistant
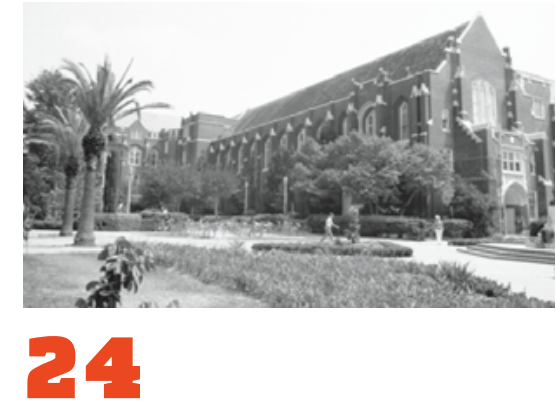

TODD C. PROSSER MEMORIAL GARDEN

Peter R. Miller

Associate Director of Facilities Planning

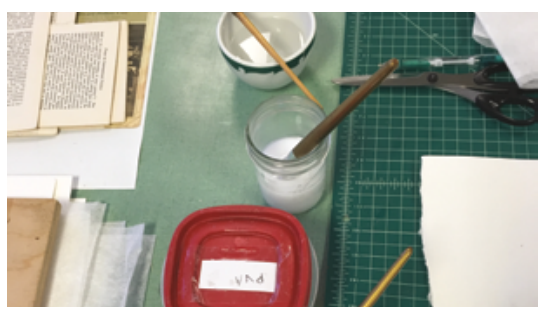

$\rightarrow 0$

\section{CONSERVATION AT UF}

Fletcher Durant

Director of Conservation \& Preservation

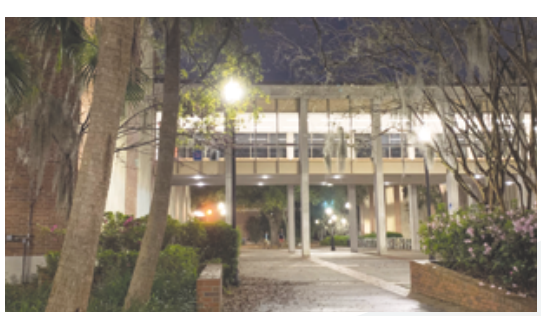

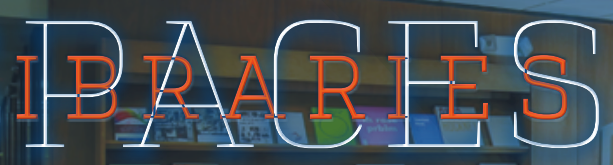

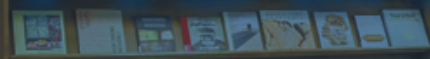

57

\section{LIBRARY SPACES -} SECOND ISSUE

\section{INTRODUCTION}

Brian W. Keith

Series Editor, Associate Dean for

Administrative Services \& Faculty Affairs

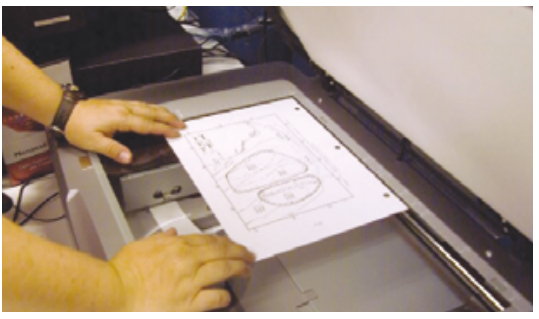

52

DIGITAL SUPPORT SERVICES \& THE UF DIGITAL COLLECTIONS

Chelsea Dinsmore

Chair of Digital Support Services

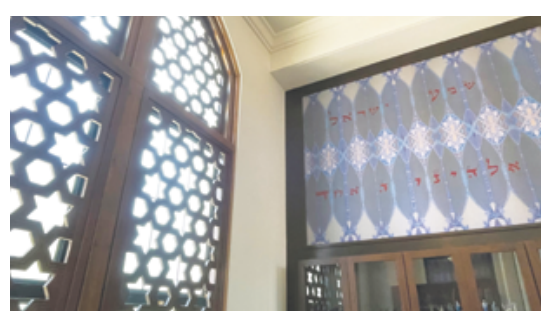

35

THE JUDAICA SUITE

Rebecca J. W. Jefferson

Curator, Isser \& Rae Price Library of Judaica

4. ARCHITECTURE \& FINE ARTS LIBRARY

Ann Lindell

Director, Architecture and Fine Arts Library

Alan Asher

Music Librarian 